\title{
Economic valuation of the environmental impact of anaerobic degradation of rice straw in the national park of the Albufera of Valencia, Spain
}

\author{
J. C. Zanchetta-Chittka \& V. A. Estruch-Guitart \\ Department of Social Sciences and Economy, \\ Polytechnic University, Valencia, Spain
}

\begin{abstract}
Straw rice cultivation in the area of the "Tancats" in the Natural Park of Albufera may suffer anaerobic degradation in humid conditions affecting water quality, impacting negatively on the lake's ecosystem. To perform the impact valuation, during the 2013-2014 season, we first enumerate ecosystem goods and services generated by the Natural Park of the Albufera. Once the services are defined we proceed by using a multi-criteria analysis (AMUVAM) based on experts to evaluate how each of the services are affected by straw anaerobic fermentation. Finally, once hierarchical relevance of impacts is settled, we obtain the total economic impact by using AMUVAM analysis.

Keywords: rice straw, anaerobic fermentation, ecosystem services, AHP, economical valuation, environmental impact, AMUVAM.
\end{abstract}

\section{Introduction}

The Albufera Natural Park is considered one of the most important wetlands of the Iberian Peninsula and the Mediterranean, both for its size and for the valuable biodiversity that it hosts (Colmenar [1]). For centuries it has been subjected to anthropogenic exploitation and transformation. This process of agricultural transformation, converting marshes and salt marshes into paddy fields, and the regulation of the hydrological functioning of the wetland to promote cultivation, has been the major cause of the modification of the original landscape of the Albufera (Ferrando and Dies Jambrino [2]). 
Rice production is the main economic use of the territory of the Albufera. It is one of the pillars that sustains the local economy, moreover agriculture is also an essential factor in maintaining the wetland ecosystem that has developed in symbiosis with it. On the one hand the cultivation ensures the maintenance of flood levels and is directly linked to both marsh and aquatic plant and animal communities, and on the other hand it maintains an agricultural landscape, rich in tradition (Díaz et al. [3]).

Every year, at the end of the cycle of rice cultivation after its harvest, the straw is left lying on the fields. Traditionally straw was removed and used for other purposes, however since the late 60 s such uses were no longer profitable and straw had been eliminated by burning it on the same fields. This practice produced huge amounts of smoke throughout the surrounding areas, emitting $\mathrm{CO}_{2}$ accumulated in plants and causing public health problems (Sanchís-Jiménez [4]).

In recent years, economical aid promoted by the EU for farmers benefiting from agro-environmental payments of the Common Agricultural Policy (CAP), prohibits the burning of straw as standard practice admitting exceptions for extraordinary cases only, such as phytosanitary emergencies. That is, farmers comply not to burn the rice straw in order to collect the EU aid (Estruch-Guitart and Planells-Valles [5]). This limitation has forced researching new ways of managing straw as pilot projects for the LIFE program of the European Commission SOST-RICE and ECO-RICE carried out by the Valencian Institute of Agricultural Research (IVIA) in collaboration with the Polytechnic University of Valencia (UPV), amongst others, where they study alternatives to burning straw. Regarding the different models for straw management, some focus on the removal from the field and subsequent revaluation of biomass waste, whilst others approach this problem by in-situ treatment and management. The latter may consist in pre-crushing straw for posterior burial or scattering of said straw on the field surface before the winter flooding. This last practice results, during the rainiest years, in the environmental impact analysed in the present work.

When the straw remains on the field and this is subsequently flooded during the winter months (October to January), this leads to the decomposition of this material by heterotrophic microorganisms that live in the water. Thus, even before the straw is completely degraded, the microbial activity will significantly reduce the concentration of dissolved oxygen in the water. This phenomenon of hypoxia/anoxia due to organic matter degrading activity by heterotrophic and aerobic microbial communities, has been widely reported even in natural aquatic environments (Hoch et al. [6]). Once in the absence of oxygen, the degradation of the rice straw will progress through the activity of anaerobic heterotrophic microorganisms, which are able to live without oxygen. These microorganisms will decompose rice straw by two main processes; fermentation or anaerobic respiration. This "anoxic" degradation of rice straw involves a greater variety of microbial types, and therefore also a diversity of end products from their metabolism (Nealson and Scott [7] and Madigan et al. [8]). However, among them, those who will have a negative effect on the overall value of the habitat, are methane $\left(\mathrm{CH}_{4}\right)$ and hydrogen sulphide $\left(\mathrm{H}_{2} \mathrm{~S}\right)$. In fact, these concentrations of hydrogen sulphide together with the absence of oxygen in water have proved 
seriously damaging in certain areas of the "tancats" park causing mass death of fish and other aquatic organisms damaging the fisheries and prejudice to the neighbouring population.

In section 2 the objective of the work is proposed and the methodology used, the expert selection and the selection of affected Ecosystem Services (ES) is justified. In point 3 we analyse the first expert consultation by which we defined the ES affected by the environmental impact. In point 4 we proceed to the second phase of the interviews where experts apply a multi-criteria analysis, this data is studied in Section 5. In Section 6 the economical valuation assessment is performed by applying the AMUVAM. Section 7 is the conclusion of this work.

\section{Objective and methodological framework}

The purpose of this paper is to present a methodology to economically assess the environmental impact generated by rice straw decomposition, under anaerobic conditions, on the ecosystem services. First the information about ecosystem services from the park will be collected and those which were affected by the impact will be identified by a first group of experts. Then through a second consultation with experts, using the methodology of Analytic Hierarchy Process (AHP) (Saaty [9]), the relevance each expert attributes to the impact on each of the services is obtained, and subsequently through an aggregation of all the values we obtain an interval of Economic Value for the Environmental Impact. There are precedents in the field of application of the AHP and updating of rents to reach an Indicator of Total Economic Value of Environmental Assets (Aznar and Estruch [10]).

\subsection{Expert selection}

To proceed with the assessment, two groups of experts have been selected. The first group is composed by experts in the park's ecosystem and pertains mainly to academic and research backgrounds. The second group is composed by the experts from the first group with the addition of professional organizations from farmers and fishermen, administration representatives, park technics and representatives of ecologist groups, all of which are listed below:

- $\quad$ Polytechnic University of Valencia (UPV).

- University of Valencia (UV).

- Fishermen Community Catarroja.

- Fishermen Community of El Palmar.

- Technical Management Office Albufera.

- Recovery Center Fauna and Flora (GVA).

- Interpretation Centre Raco l' Olla (GVA).

- Acció Ecologista.

- Tancat de la Pipa.

- AVA-ASAJA Cooperative. 
- $\quad$ Assut Foundation - Sat Rice Growers Pinedo Valencia.

- Piscifactoria the Palmar (LIFE).

\subsection{Ecosystem services definition}

The concept of ecosystem services and its consideration for environmental economic valuation has been the result of intense debate on different fronts, but it is possible to define within a particular conceptual framework to define and analyse reality from within it (Boyd and Banzhaf [11]). For this analysis we will take as an ecosystem service those aspects of the ecosystem used directly or indirectly to generate human well-being (Fisher and Turner [12]). Also we consider the differentiation between ecosystem services that we will value and benefits of these services in order to avoid possible double counting when making economic valuation, considering and accounting for only the final ecosystem services (Boyd and Banzhaf [11]). Similarly, we consider that another defining characteristic for these to be considered as ES is to be ecological processes in nature, considering also the Cultural Services as a component of the SE (Wallace [13] and MA [14]).

\subsection{Analytic Hierarchy Process (AHP)}

The AHP (Saaty [9]) is a method which helps decision making, widely used in various professional and business fields. Allowing to prioritise a set of alternatives by a paired comparison between components through a fundamental scale designed for this purpose (Table 1).

Table 1: $\quad$ Scale of comparison (Saaty [9]).

\begin{tabular}{cll}
\hline $\begin{array}{c}\text { Intensity of } \\
\text { Importance }\end{array}$ & Defmition & Explanation \\
\hline 1 & Equal importance & Two activities have equal contribute to the objective \\
3 & Moderate importance & Experience and judgment slightly favor one activity over another. \\
5 & Strong importance & Experience and judgment strongly favor one activity over another \\
7 & Very strong on demonstrated importance & An activity is favored very strongly over another \\
9 & Extreme importance & $\begin{array}{l}\text { The evidence favoring one activity over another is of the highest possible } \\
\text { order of affirmation }\end{array}$ \\
$2,4,6,8$ & For compromise between the above values & Sometimes one needs to interpolate a compromise judgment numerically \\
\hline
\end{tabular}

Comparing two by two alternatives based on one criteria, and using the scale box of pairwise comparison we obtain square matrices $\mathrm{A}=\mathrm{a}_{\mathrm{ij}}$ that meet the properties of reciprocity, homogeneity and consistency.

The eigenvector $\mathrm{v}_{\mathrm{ai}}$ of the proposed matrix indicates the importance or weight of each alternative based on that criterion.

AHP also evaluates the inconsistency of the decider when making judgments by calculating the so-called consistency ratio (CR). Overall, inconsistencies are accepted below $10 \%$ for matrices of rank $n>4(5 \%$ for $n=3$ and $8 \%$ for $n=4)$ (Saaty [9]). If these conditions are not met, the judgments should be revised or the matrices discarded. 
In this paper, unlike a classic model of AHP and previous work on assessment, prioritization is performed by taking into account a single criterion, so that the paired comparison is used only to answer the question "between these two ecosystem services affected by the environmental impact, which is considered to be most affected, and with what intensity". The resulting matrix corresponding to the eigenvector of this process indicates the weighting or relative importance of all the ES considered.

\section{Environmental impact on ecosystem services}

During the first phase of the study, individual interviews with a group of experts were conducted in order to determine which ecosystem services were directly affected by the impact produced due to the anaerobic fermentation of straw. For this, the following procedure was followed:

- Subjects were exposed to the definition of ES spelled out in 2.2, differentiating between intermediate services, final services and benefits derived from them (Boyd and Banzhaf [11]).

- Then the different strategies of the rice straw management in the park and the physical and chemical processes of anaerobic fermentation were explained to them (Hoch et al. [6]) (as mentioned at the end of section 1 of this work).

- Afterwards, these experts were presented with a categorization of ecosystem services to provide a basis from which to perform the valuation (Figure 1), "The Economics of Ecosystems and Biodiversity" [15].

- Once presented with the diagram the experts were asked to list those ES which they judged were directly affected by the impact.

After discussing the results obtained the group of experts agreed on the ES affected by the environmental impact. These services were:

- $\quad$ S1. Fishing (provisioning service).

- $\quad$ S2. Water quality (provisioning service).

- $\quad$ S3. Habitat for species (habitat service).

- S4. Maintenance of genetic diversity (supporting service).

- S5. Cultural services. 


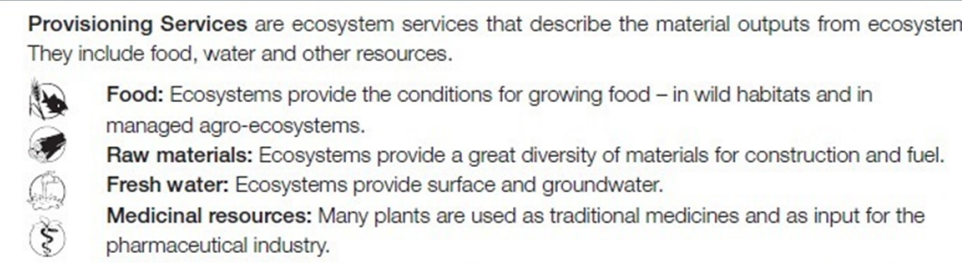

Regulating Services are the services that ecosystems provide by acting as regulators eg regulating the quality of air and soil or by providing flood and disease control.

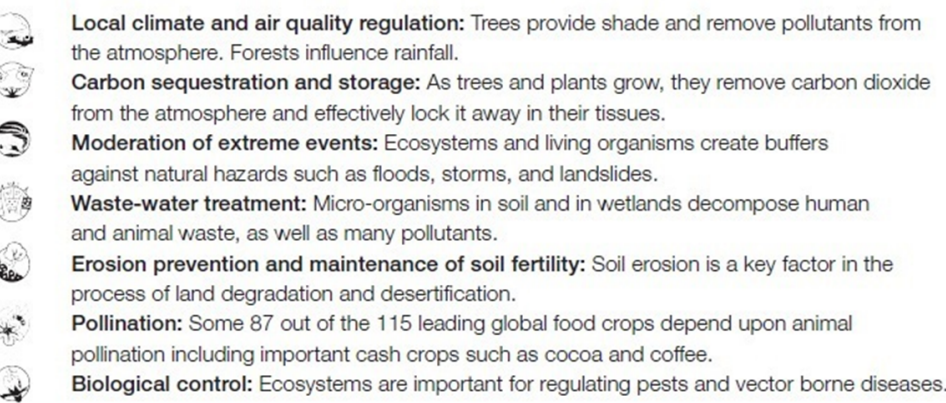

Habitat or Supporting Services underpin almost all other services. Ecosystems provide living spaces for plants or animals; they also maintain a diversity of different breeds of plants and animals.

53 Habitats for species: Habitats provide everything that an individual plant or animal needs to survive. Migratory species need habitats along their migrating routes.

Maintenance of genetic diversity: Genetic diversity distinguishes different breeds or races, providing the basis for locally well-adapted cultivars and a gene pool for further developing commercial crops and livestock.

Cultural Services include the non-material benefits people obtain from contact with ecosystems. They include aesthetic, spiritual and psychological benefits.

i) Recreation and mental and physical health: The role of natural landscapes and urban green space for maintaining mental and physical health is increasingly being recognized.

3. Tourism: Nature tourism provides considerable economic benefits and is a vital source of income for many countries.

(C) Aesthetic appreciation and inspiration for culture, art and design: Language, knowledge and appreciation of the natural environment have been intimately related throughout human history.

Spiritual experience and sense of place: Nature is a common element of all major religions; natural landscapes also form local identity and sense of belonging.

Icons designed by Jan Sasse for TEEB. They are available for download at www.teebweb.org

Figure 1: TEEB [15] "The Economics of Ecosystems and Biodiversity: Mainstreaming the Economics of Nature: A synthesis of the approach, conclusions and reccomendations of the TEEB".

\section{Interviews: multicriteria application}

During the second phase of the study, experts were interviewed individually in sessions, for an average of 30 minutes, during which they were presented with a series of descriptive questions about the professional reality of these and their general views of the context in which the park is circumscribed. Once these 
questions were answered, they were asked to fill in the matrix of pairwise comparisons multi-criteria on which once the consistency ratios where verified, ruling or restating those inconsistent, the eigenvectors corresponding to each ES (Table 2) were calculated.

Table 2: Eigenvectors and consistency ratio.

\begin{tabular}{|c|c|c|c|c|c|c|}
\hline Expert & Service 1 & Service 2 & Service 3 & Service 4 & Service 5 & $\begin{array}{c}\text { Consistency } \\
\text { ratio }(\%) \\
\end{array}$ \\
\hline 1 & 0.44 & 0.22 & 0.14 & 0.04 & 0.16 & 8.69 \\
\hline 2 & 0.37 & 0.18 & 0.18 & 0.13 & 0.13 & 9.65 \\
\hline 3 & 0.04 & 0.55 & 0.15 & 0.13 & 0.13 & 5.90 \\
\hline 4 & 0.06 & 0.22 & 0.04 & 0.30 & 0.38 & 5.83 \\
\hline 5 & 0.38 & 0.09 & 0.04 & 0.06 & 0.43 & 9.01 \\
\hline 6 & 0.45 & 0.26 & 0.11 & 0.15 & 0.03 & 9.43 \\
\hline 7 & 0.38 & 0.38 & 0.10 & 0.11 & 0.03 & 8.83 \\
\hline 8 & 0.28 & 0.28 & 0.05 & 0.28 & 0.12 & 3.48 \\
\hline 9 & 0.05 & 0.58 & 0.14 & 0.19 & 0.05 & 7.86 \\
\hline 10 & 0.03 & 0.29 & 0.24 & 0.38 & 0.06 & 8.94 \\
\hline 11 & 0.53 & 0.25 & 0.04 & 0.06 & 0.11 & 9.65 \\
\hline 12 & 0.08 & 0.24 & 0.37 & 0.28 & 0.03 & 8.88 \\
\hline 13 & 0.28 & 0.52 & 0.08 & 0.07 & 0.05 & 9.25 \\
\hline 14 & 0.33 & 0.29 & 0.03 & 0.26 & 0.09 & 8.95 \\
\hline 15 & 0.03 & 0.28 & 0.06 & 0.08 & 0.55 & 8.49 \\
\hline 16 & 0.21 & 0.55 & 0.08 & 0.08 & 0.08 & 3.39 \\
\hline 17 & 0.09 & 0.45 & 0.11 & 0.32 & 0.04 & 8.41 \\
\hline 18 & 0.49 & 0.26 & 0.07 & 0.11 & 0.08 & 8.99 \\
\hline 19 & 0.20 & 0.20 & 0.20 & 0.20 & 0.20 & 0.00 \\
\hline 20 & 0.39 & 0.40 & 0.05 & 0.13 & 0.03 & 7.78 \\
\hline 21 & 0.10 & 0.27 & 0.37 & 0.20 & 0.05 & 4.11 \\
\hline 22 & 0.07 & 0.47 & 0.19 & 0.19 & 0.07 & 1.25 \\
\hline 23 & 0.08 & 0.30 & 0.27 & 0.27 & 0.09 & 0.71 \\
\hline 24 & 0.06 & 0.49 & 0.20 & 0.21 & 0.03 & 9.13 \\
\hline 25 & 0.34 & 0.06 & 0.40 & 0.15 & 0.06 & 5.68 \\
\hline
\end{tabular}

As shown in table 2, the distribution of the values of the eigenvectors within each ES, we observe that the values given are quite heterogeneous at intervals. Service S1 with an average $=0.23$ and std.deviation $=0.16$, and S2 with average $=0.32$ and std.deviation $=0.14$, are both the services that present more variability. For this reason and in order to obtain a weighted aggregation of eigenvectors according the methodology of aggregation of the geometric mean, we perform a statistical data analysis to identify trends within the group of experts (Aczél and Saaty [16], Forman and Peniwati [17], Gass and Rapcsák [18]). 


\section{Conglomerate analysis: ANOVA application}

By a multivariate cluster analysis technique, we established three groups over which we have conducted an analysis of variance (ANOVA) and a post- hoc test to establish existing patterns between groups framed within each ES (Table 3).

Table 3: Post-hoc Scheffé test (source: own elaboration).

\begin{tabular}{|c|c|c|c|c|c|c|c|c|}
\hline \multicolumn{9}{|l|}{ Scheffé } \\
\hline \multirow{2}{*}{$\begin{array}{l}\text { Variable } \\
\text { dependiente }\end{array}$} & \multirow{2}{*}{$\begin{array}{l}\text { (I) Average } \\
\text { Linkage } \\
\text { (Between } \\
\text { Groups) }\end{array}$} & \multirow{2}{*}{\multicolumn{2}{|c|}{$\begin{array}{l}\text { (J) Average } \\
\text { Linkage } \\
\text { (Between } \\
\text { Groups) }\end{array}$}} & \multirow{2}{*}{$\begin{array}{l}\text { Diferencia de } \\
\text { medias (I-J) }\end{array}$} & \multirow{2}{*}{ Error típico } & \multirow{2}{*}{ Sig. } & \multicolumn{2}{|c|}{ Intervalo de confianza al $95 \%$} \\
\hline & & & & & & & Límite inferior & Límite superior \\
\hline \multirow{6}{*}{ s1 } & \multirow{2}{*}{\multicolumn{2}{|c|}{ 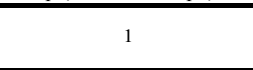 }} & 2 &, $2837273^{4}$ & 0,0431352 & 0 & 0,170529 & 0,396925 \\
\hline & & & 3 &, $2248182^{*}$ & 0,0658902 & 0,009 & 0,051906 & 0,397731 \\
\hline & \multirow{2}{*}{\multicolumn{2}{|c|}{2}} & 1 &,$- 2837273^{4}$ & 0,0431352 & 0 & $-0,396925$ & $-0,170529$ \\
\hline & & & 3 & $-0,0589091$ & 0,0658902 & 0,675 & $-0,231822$ & 0,114004 \\
\hline & \multirow{2}{*}{\multicolumn{2}{|c|}{3}} & 1 &,$- 2248182^{+}$ & 0,0658902 & 0,009 & $-0,397731$ & $-0,051906$ \\
\hline & & & 2 & 0,0589091 & 0,0658902 & 0,675 & $-0,114004$ & 0,231822 \\
\hline \multirow{12}{*}{ s2 } & \multirow{2}{*}{\multicolumn{2}{|c|}{1}} & 2 &,$- 1737273^{4}$ & 0,047037 & 0,005 & $-0,297164$ & $-0,05029$ \\
\hline & & & 3 & 0,0565758 & 0,0718502 & 0,737 & $-0,131978$ & 0,245129 \\
\hline & \multirow{2}{*}{\multicolumn{2}{|c|}{2}} & 1 &, $1737273^{*}$ & 0,047037 & 0,005 & 0,05029 & 0,297164 \\
\hline & & & 3 & ,2303030* & 0,0718502 & 0,015 & 0,04175 & 0,418856 \\
\hline & \multirow{2}{*}{\multicolumn{2}{|c|}{3}} & 1 & $-0,0565758$ & 0,0718502 & 0,737 & $-0,245129$ & 0,131978 \\
\hline & & & 2 &,$- 2303030^{*}$ & 0,0718502 & 0,015 & $-0,418856$ & $-0,04175$ \\
\hline & \multirow{2}{*}{\multicolumn{2}{|c|}{1}} & 2 & $-0,0757273$ & 0,0427723 & 0,231 & $-0,187973$ & 0,036518 \\
\hline & & & 3 & 0,078303 & 0,0653358 & 0,499 & $-0,093155$ & 0,249761 \\
\hline & \multirow{2}{*}{\multicolumn{2}{|c|}{2}} & 1 & 0,0757273 & 0,0427723 & 0,231 & $-0,036518$ & 0,187973 \\
\hline & & & 3 & 0,1540303 & 0,0653358 & 0,084 & $-0,017427$ & 0,325488 \\
\hline & \multirow{2}{*}{\multicolumn{2}{|c|}{3}} & 1 & $-0,078303$ & 0,0653358 & 0,499 & $-0,249761$ & 0,093155 \\
\hline & & & 2 & $-0,1540303$ & 0,0653358 & 0,084 & $-0,325488$ & 0,017427 \\
\hline \multirow{6}{*}{$s 4$} & \multirow{2}{*}{\multicolumn{2}{|c|}{1}} & 2 & $-0,0665455$ & 0,0387072 & 0,25 & $-0,168123$ & 0,035032 \\
\hline & & & 3 & $-0,0012727$ & 0,0591263 & 1 & $-0,156435$ & 0,15389 \\
\hline & \multirow{2}{*}{\multicolumn{2}{|c|}{2}} & 1 & 0,0665455 & 0,0387072 & 0,25 & $-0,035032$ & 0,168123 \\
\hline & & & 3 & 0,0652727 & 0,0591263 & 0,553 & $-0,08989$ & 0,220435 \\
\hline & \multirow{2}{*}{\multicolumn{2}{|c|}{3}} & 1 & 0,0012727 & 0,0591263 & 1 & $\begin{array}{l}-0,15389 \\
\end{array}$ & 0,156435 \\
\hline & & & 2 & $-0,0652727$ & 0,0591263 & 0,553 & $-0,220435$ & 0,08989 \\
\hline \multirow{6}{*}{$\mathrm{s} 5$} & \multirow{2}{*}{\multicolumn{2}{|c|}{1}} & 2 & 0,0320909 & 0,0216281 & 0,35 & $-0,024667$ & 0,088848 \\
\hline & & & 3 &,$- 3585152^{*}$ & 0,0330374 & 0 & $-0,445214$ & $-0,271817$ \\
\hline & \multirow{2}{*}{\multicolumn{2}{|c|}{2}} & 1 & $-0,0320909$ & 0,0216281 & 0,35 & $-0,088848$ & 0,024667 \\
\hline & & & 3 &,$- 3906061^{*}$ & 0,0330374 & 0 & $-0,477305$ & $-0,303908$ \\
\hline & \multirow{2}{*}{\multicolumn{2}{|c|}{3}} & 1 &, $3585152^{4}$ & 0,0330374 & 0 & 0,271817 & 0,445214 \\
\hline & & & 2 & ,3906061" & 0,0330374 & 0 & 0,303908 & 0,477305 \\
\hline
\end{tabular}

From these analyses we establish that these three subgroups within the surveyed experts differ significantly, especially regarding their value judgments as to the significance of the considered impact on fishing, water quality and cultural services. Of these three groups both 1 and 2 represent $44 \%$ of the sampled population each, while group 3 only represents $12 \%$. Another significant factor observed is a differentiation between groups 1 and 2; while group 1 is made up almost entirely of components within the research and university's context, group 2 instead consists predominantly of representatives of the fisheries sector, agriculture and park technicians. This fluctuation is probably due to the different conceptions of reality and the experience between groups. While the first group 
has intervened in various studies and previous interventions in the park repeatedly over time, the second group has experienced a more direct, day-to-day, relationship with the reality of the park. This is probably reflected in an accentuation of what they consider as the most affected service by the anaerobic fermentation of straw, the fishing service.

Because of this fluctuation as to the ratings of each service and in order to get the economic value of the impact, we obtain the eigenvectors (Table 5) of each of these to calculate, according to the methodology aggregation of the geometric mean the weighted aggregation eigenvectors (Aczél and Saaty [16], Forman and Peniwati [17], Gass and Rapcsák [18]).

\section{Economic value of the environmental impact}

In order to calculate the economic value of the environmental impact we start from a pivot value, which in this case is the fishing service, because the impact effects can be directly correlated economically to losses and declines in catches, which are easily documented. To get such data, we have consulted the databases of the Fishing Community of El Palmar and have used as reference the season before and after the environmental problem took place during the year 2013. We have considered the losses in eel catches, since they are the specie that has been most significantly affected in these periods during which the problem of straw fermentation has been considerable (Table 4).

Table 4: $\quad$ Eel catches (source: Comunidad de Pescadores del Palmar).

\begin{tabular}{|lrrrrr|}
\hline Year & Anguila maresa $(\mathrm{kg})$ & Anguila pasturenca $(\mathrm{kg})$ & Total $(\mathrm{kg})$ & \multicolumn{1}{c|}{ Stock Price (eur.) } & Total (eur.) \\
\hline \hline $2012-13$ & 3628 & 1911 & 5539 & 8 & 44312 \\
$2013-14$ & 2473 & 363 & 2836 & 7 & 19852 \\
& & & & Estimated Losses & 24460 \\
\hline
\end{tabular}

Table 5: AMUVAM (source: own elaboration).

\begin{tabular}{|ccccccc|}
\hline & Group 1 & & & \multicolumn{3}{c|}{ Group 2 } \\
Service & Value (eur.) & Eigenvector & & Service & Value (eur.) & Eigenvector \\
\hline \hline S1 & 24460,00 & 0,3606 & & S1 & 24460,00 & 0,0912 \\
S2 & 19631,85 & 0,2894 & & S2 & 117080,55 & 0,4366 \\
S3 & 7629,68 & 0,1125 & & S3 & 53436,89 & 0,1993 \\
S4 & 10321,71 & 0,1522 & & S4 & 56544,78 & 0,2108 \\
S5 & 5787,71 & 0,0853 & & S5 & 16654,96 & 0,0621 \\
Total Value & 67830,95 & & & Total Value & 268177,19 & \\
& & & & & & \\
& Group 3 & & & & & \\
Service & Value (eur.) & Eigenvector & & & & \\
\hline \hline S1 & 24460,00 & 0,1024 & & & & \\
S2 & 48973,50 & 0,2051 & & & & \\
S3 & 12270,89 & 0,0514 & & & & \\
S4 & 30839,20 & 0,1291 & & & & \\
S5 & 122258,52 & 0,5120 & & & & \\
Total Value & 238802,11 & & & & & \\
\hline
\end{tabular}


Having the economical estimated losses of 24,460 Euros, and the eigenvectors of the fishing service (S1), we estimate through the multi-criteria valuation methodology AMUVAM (Aznar and Estruch [10]) the total value of the environmental impact according to each of the subgroups of experts (Table 5). Doing so we can assess that the value of the environmental impact occurring on the year of 2013 has fluctuated in a range between $67.380,85$ and $268.177,19$ Euros.

\section{Conclusions}

The proposed assessment method allows us to estimate a range of economic value generated in the park as a result of the impact produced by the anaerobic decomposition of the straw that occurred between the seasons of 2012-13 and 2013-14. It has the advantage of considering only those experts who are consistent in their views. It sets a value interval, for although the impact on services that have a market is the same, the importance attached to the other services that have no market differs depending on the different existing positions. This difference in the importance given by the experts can be seen in the degree of the interval amplitude obtained. It should be noted that this valuation methodology consists of an anthropocentric approach because it is based on judgments that may differ more or less depending on the reality and context of each of the individuals interviewed. This factor allows the representation of the plurality of judgments and opinions inherent human reality. That is why we believe that this methodology may serve well as a very interesting tool to apply in assessing environmental impacts where there is a significant convergence of disparate interests between governments, corporations, unions and other groups, therefore serving as a starting point in managing environmental impacts.

\section{References}

[1] Colmenar, Eloisa. "Objetivo prioritario, proteger: plan de saneamiento de L'Albufera de Valencia." Ambienta: la revista del Ministerio de Medio Ambiente 1 (2001): pp. 46-49.

[2] Ferrando, José Segarra, and Bosco Dies Jambrino. "54. El parc natural de l'Albufera. Un paisaje cultural cargado de historia." revista ph 85 (2014).

[3] Díaz, César Alvarez, et al. "Análisis del comportamiento ambiental de l'Albufera de Valencia. " Litoral, ordenación y modelos de futuro: IV Congreso de Ingeniería Civil, Territorio y Medio Ambiente, 2010.

[4] Sanchís Jiménez, EM. (2014). Emisiones de gases en el cultivo del arroz: efecto de la gestión de la paja. http://hdl.handle.net/10251/47780.

[5] Estruch-Guitart, Vicent and Planells-Valles María. "Elementos de debate en torno a la política agroambiental. El caso del Parque nacional de la Albufera." (2002).

[6] Hoch, B., Berger, B., Kavka, G., Herndll, G.J., 1995. Remineralization of organic matter and degradation of the organic fraction of suspended solids in the River Danube. Aquat. Microb. Ecol. 9: pp. 279-288. Madigan. 
[7] Nealson, K.H., Scott, J., 2006. Ecophisiology of the genus Shewanella (Chapter Stackebrandt, E.(eds). The Prokaryotes, A Handbook on the Biology of Bacteria, 3rd edition. vol 6: Proteobacteria: Gamma Subclass, pp. 1133-1151. Springer.

[8] Madigan, T.M., Martinko, J.M., Dunlap, P.V., Clark, D.P., 2012. Ciclos de los nutrients, biorremediación y simbiosis: ciclos del carbono y del oxígeno (capítulo 24) En: Mardigan et al. (eds.) pp. 769-771. Pearson.

[9] Saaty, T. (1980). The Analytic Hierarchy Process. RWS Publications, Pittsburgh.

[10] Aznar, Jerónimo, and Vicente Estruch. "Valoración de activos ambientales mediante métodos multicriterio. Aplicación a la valoración del Parque Natural del Alto Tajo." Economía agraria y recursos naturales 7.13 (2007): pp. 107-126.

[11] Boyd, J., Banzhaf, S., 2007. "What are ecosystem services? Ecological Economics" 63 (2-3), pp. 616-626.

[12] Fisher, Brendan, and R. Kerry Turner. "Ecosystem services: classification for valuation." Biological conservation 141.5 (2008): pp. 1167-1169.

[13] Wallace, K.J., 2007. "Classification of ecosystem services: problems and solutions. Biological Conservation" 139, pp. 235-246.

[14] MA (2005), Millennium Ecosystem Assessment Ecosystems and Human Well-Being: Synthesis, 2005. Island Press, Washington, DC.

[15] TEEB (2010) "The Economics of Ecosystems and Biodiversity: Mainstreaming the Economics of Nature: A synthesis of the approach, conclusions and recommendations of the TEEB."

[16] Aczél, J. and Saaty, T.L. (1983). "Procedures for Synthesizing Ratio Judgments". Journal of Mathematical Psychology, 27: pp. 93-102.

[17] Forman, E. and Peniwati, K. (1998). "Aggregating Individual Judgments and Priorities with the Analytic Hierarchy Process". European Journal of Operational Research, 108: pp. 165-169.

[18] Gass, S.I. and Rapcsák, T. (1998). "A note on Synthesizing Group Decisions". Decision Support Systems, 22: pp. 59-63. 